\title{
Who dies from hernia?
}

\author{
Anne M Reaveley, Jonathan S Nguyen-Van-Tam, Richard F A Logan
}

Over 700 deaths in England and Wales each year are ascribed to an underlying cause of abdominal hernia, considerably more than for cholelithiasis, pancreatitis or inflammatory bowel disease. ${ }^{1}$ Abdominal hernias are considered amenable to surgical intervention, therefore hernia mortality is regarded as largely avoidable. ${ }^{2}$ None the less substantial variations in mortality exist at district level within the United Kingdom (UK). ${ }^{2}$ Age standardised mortality among persons aged 5-64 years (0.20 deaths $/ 10^{5}$ persons) ranks third across Europe after France $\left(0.26 / 10^{5}\right)$ and Italy $\left(0.25 / 10^{5}\right)$, and is double the lowest rate observed. ${ }^{3}$ To try to identify possible reasons for this we reviewed all hernia deaths in a single English health district over a six year period.

\section{Methods and results}

From a database provided by the Office for National Statistics we identified all residents who died between 1.1 .89 and 31.3 .95 whose underlying cause of death had been ascribed to abdominal hernia (ICD-9-CM codes 550553). By reference to general practitioner (GP) case notes and hospital records, data were collected on demography, past history of hernia, presenting symptoms, and treatment during final illness.

Sixty nine cases were identified; virtually all underwent postmortem examination, which confirmed the cause of death. Table 1 summarises the available data, subdivided into the major categories of abdominal hernia. While the majority of deaths were ascribed to either inguinal or femoral hernias, just under one third were ascribed to diaphragmatic (hiatus) hernias where the immediate cause of death usually related to gastrointestinal haemorrhage or a cardiopulmonary complication such as pulmonary embolism, bronchopneumonia or congestive cardiac failure. Although those who died tended to be very elderly, $11(16 \%)$ were under 70 years of age.
Among those who died from inguinal hernia most were elderly men and half had a history of hernia at the same site documented in GP records. The vast majority presented with symptoms of strangulation and were admitted to hospital; obstruction or gangrene was considered to be present in over half, yet over $80 \%$ did not undergo surgery; in most cases it was not possible to tell why this had been the case. In contrast, those who died from femoral hernia were mainly elderly women; almost all presented with symptoms of strangulation and most were admitted to hospital; obstruction or gangrene was considered to be present in $85 \%$ of cases and $62 \%$ underwent surgery.

\section{Comment}

Abdominal hernia is a common complaint, which, in Britain, causes 700 persons $/ 10^{5}$ population to consult with their GP each year; in both men and women prevalence rises sharply with age. ${ }^{4}$ Because hernia deaths are considered "avoidable", death rates are considered to be a useful indicator for judging the efficiency and effectiveness of health care services. $^{2}$ The tabulated data suggest that in England and Wales about $30 \%$ of deaths ascribed to abdominal hernia (approximately 200 per annum) are in fact due to diaphragmatic hernia where the underlying pathology is usually peptic oesophagitis. ${ }^{2}$ Deaths from nonmalignant oesophageal disease have risen in recent years ${ }^{5}$; as most of these are not considered suitable for surgery, we suggest they should be excluded when calculating avoidable deaths ascribed to abdominal hernia. Indeed, certification practice with respect to diaphragmatic hernia may contribute to the observed variations in hernia death rate across Europe.

In retrospective studies such as this it is difficult to assess the avoidability of death. However, with regard to inguinal hernias, which are normally considered curable by surgery, two distinct trends were apparent. Firstly, in half of those who died the hernia had been diagnosed before their final illness, yet almost all presented

Table 1 Hernia deaths in Nottingham residents, fanuary 1989-March 1995

\begin{tabular}{|c|c|c|c|c|c|c|c|c|c|c|c|c|c|c|c|c|c|c|c|c|}
\hline \multirow{2}{*}{$\begin{array}{l}\text { Category of } \\
\text { hernia }\end{array}$} & \multirow[b]{2}{*}{ No } & \multirow[b]{2}{*}{$(\%)$} & \multirow{2}{*}{$\begin{array}{l}\text { Malel } \\
\text { female }\end{array}$} & \multirow{2}{*}{$\begin{array}{l}\text { Median } \\
\text { age } \\
\text { (y) }\end{array}$} & \multicolumn{2}{|c|}{$\begin{array}{l}\text { Documented } \\
\text { history of } \\
\text { herniat }\end{array}$} & \multicolumn{2}{|c|}{$\begin{array}{l}\text { Contact } \\
\text { with GP } \\
\text { during final } \\
\text { illness }\end{array}$} & \multicolumn{2}{|c|}{$\begin{array}{l}\text { Symptoms } \\
\text { of } \\
\text { strangulation }\end{array}$} & \multicolumn{2}{|c|}{$\begin{array}{l}\text { Obstruction } \\
\text { or gangrene } \\
\text { present }\end{array}$} & \multicolumn{2}{|c|}{$\begin{array}{l}\text { Hospital } \\
\text { admission } \\
\text { during final } \\
\text { illness }\end{array}$} & \multicolumn{2}{|c|}{$\begin{array}{l}\text { Surgery } \\
\text { during final } \\
\text { illness }\end{array}$} & \multicolumn{2}{|c|}{$\begin{array}{l}\text { Died in } \\
\text { hospital }\end{array}$} & \multicolumn{2}{|c|}{$\begin{array}{l}\text { Postmortem } \\
\text { examination }\end{array}$} \\
\hline & & & & & No & $(\%)$ & No & $(\%)$ & No & $(\%)$ & No & $(\%)$ & No & $(\%)$ & No & $(\%)$ & No & $(\%)$ & No & $(\%)$ \\
\hline Inguinal & 23 & (33) & $19 / 4$ & 79 & $10 / 20$ & $(50)$ & $16 / 22$ & (73) & $19 / 23$ & (83) & $12 / 23$ & $(52)$ & $18 / 23$ & (78) & $4 / 23$ & (17) & $18 / 23$ & (78) & $20 / 23$ & (87) \\
\hline Femoral & 13 & (19) & $1 / 12$ & 82 & $2 / 12$ & (17) & $11 / 13$ & (85) & $12 / 13$ & (92) & $11 / 13$ & (85) & $10 / 13$ & (77) & $8 / 13$ & (62) & $10 / 13$ & (77) & $11 / 13$ & (85) \\
\hline Diaphragmatic & 20 & (29) & $5 / 15$ & 81 & $17 / 19$ & $(89)$ & $11 / 19$ & (58) & $6 / 16$ & (38) & $1 / 20$ & (5) & $15 / 20$ & (75) & $3 / 20$ & (15) & $15 / 20$ & (75) & $15 / 16$ & (94) \\
\hline Other ${ }^{\star}$ & 13 & (19) & $4 / 9$ & 76 & $6 / 11$ & (55) & $7 / 12$ & (58) & $8 / 9$ & (89) & $9 / 13$ & (69) & $10 / 12$ & (83) & $3 / 12$ & (25) & $10 / 13$ & (77) & $8 / 11$ & (73) \\
\hline Total & 69 & (100) & $29 / 40$ & 80 & $35 / 62$ & (56) & $45 / 66$ & (68) & $45 / 61$ & (74) & $33 / 69$ & (48) & $53 / 68$ & (78) & $18 / 68$ & (26) & $53 / 69$ & (77) & $54 / 63$ & (86) \\
\hline
\end{tabular}

${ }^{\star}$ Comprising of seven ventral hernias, three internal hernias, one umbilical hernia, one spigelian hernia and one of unspecified type. †According to GP notes. 
with symptoms of strangulation; this suggests that more patients should have been considered for early elective repair, even in the absence of symptoms. Secondly, while $78 \%$ of patients were admitted to hospital, only $17 \%$ underwent an operation; this may indicate that emergency surgery should have been attempted more often. Deaths such as these, which did not involve an operation, fall outside the remit of the National Confidential Enquiry into Perioperative Deaths (NCEPOD), ${ }^{6}$ but none the less warrant further investigation through the audit process.

Source of funding: none Conflicts of interest: none
1 Office for National Statistics. Mortality statistics: cause. Review of the Registrar General on deaths by cause, sex and age, in England and Wales, 1993 (revised) and 1994. London: HMSO, 1996.

2 Charlton JRH, Hartley RM, Silver R, et al. Geographical variation in mortality from conditions amenable to medical intervention in England and Wales. Lancet 1983;i:691-6.

3 Holland WW, Paul EA, Barry J, et al. (EC Working Group on Health Services and "Avoidable Deaths"). European Community atlas of "avoidable death". 2nd ed. Vol 1 Oxford: Oxford University Press, 1991.

4 McCormick A, Fleming D, Charlton J. Morbidity statistics from general practice. Fourth national study, 1991-1992. from general practice. Four

5 Panos MZ, Walt RP, Stevenson C, et al. Rising death rate from non-malignant disease of the oesophagus (NMOD) in England and Wales. Gut 1995;36:488-91.

6 Campling EA, Devlin HB, Hoile RW, et al. The Report of the National Confidential Enquiry into Perioperative Deaths 1992/ 1993. London: National Confidential Enquiry into Perioperative Deaths, 1995. 